\title{
Differentiating Digital Twin from Digital Shadow: Elucidating a Paradigm Shift to Expedite a Smart, Sustainable Built Environment
}

\author{
Samad M. E. Sepasgozar (D)
}

Citation: Sepasgozar, S.M.E. Differentiating Digital Twin from Digital Shadow: Elucidating a Paradigm Shift to Expedite a Smart, Sustainable Built Environment. Buildings 2021, 11, 151. https:// doi.org/10.3390/buildings11040151

Academic Editor: Derek

Clements-Croome

Received: 24 February 2021

Accepted: 31 March 2021

Published: 2 April 2021

Publisher's Note: MDPI stays neutral with regard to jurisdictional claims in published maps and institutional affiliations.

Copyright: (C) 2021 by the author. Licensee MDPI, Basel, Switzerland. This article is an open access article distributed under the terms and conditions of the Creative Commons Attribution (CC BY) license (https:// creativecommons.org/licenses/by/ $4.0 /)$.
School of Built Environment, Faculty of Arts, Design \& Architecture, University of New South Wales, Sydney 2052, Australia; sepas@unsw.edu.au

\begin{abstract}
Construction projects and cities account for over $50 \%$ of carbon emissions and energy consumption. Industry 4.0 and digital transformation may increase productivity and reduce energy consumption. A digital twin (DT) is a key enabler in implementing Industry 4.0 in the areas of construction and smart cities. It is an emerging technology that connects different objects by utilising the advanced Internet of Things (IoT). As a technology, it is in high demand in various industries, and its literature is growing exponentially. Previous digital modeling practices, the use of data acquisition tools, human-computer-machine interfaces, programmable cities, and infrastructure, as well as Building Information Modeling (BIM), have provided digital data for construction, monitoring, or controlling physical objects. However, a DT is supposed to offer much more than digital representation. Characteristics such as bi-directional data exchange and real-time self-management (e.g., self-awareness or self-optimisation) distinguish a DT from other information modeling systems. The need to develop and implement DT is rising because it could be a core technology in many industrial sectors post-COVID-19. This paper aims to clarify the DT concept and differentiate it from other advanced 3D modeling technologies, digital shadows, and information systems. It also intends to review the state of play in DT development and offer research directions for future investigation. It recommends the development of DT applications that offer rapid and accurate data analysis platforms for real-time decisions, self-operation, and remote supervision requirements post-COVID-19. The discussion in this paper mainly focuses on the Smart City, Engineering and Construction (SCEC) sectors.
\end{abstract}

Keywords: digital shadow; digital twin; sensor; internet of things; smart city; engineering; construction; energy; cyber-physical; deep learning; blockchain; Intelligent construction 4.0

\section{Introduction}

The exponential development of technology in recent years is highlighted by the concept of Industry 4.0 and respective initiatives in various contexts of the Smart City, Engineering and Construction (SCEC) sectors, such as Building 4.0 [1], Real Estate 4.0 [2], Construction 4.0 [3-6], Mining 4.0 [7,8], Education 4.0 [9-11], and Manufacturing 4.0 [12,13]. The Industry 4.0 concept relies on connecting physical environments with digital ecosystems. At present, there is a demand to investigate advanced automation, the implementation of robotics, improvements in machine-to-machine (M2M) communication, and human-to-machine or human-computer-machine communications [14]. Digital Twin (DT) facilitates the connectivity required for such developments through many self-operative functionalities. However, the DT concept and its capacity have not been distinguished from current computing or virtual models and simulations [15]. This paper aims to discuss DT, review the state of play, and present future directions of DT development and applications.

Before distinguishing DT from other current practices, it is vital to clarify whether DT can be considered a technology. This is essential to present a consistent understanding of the context and to align thinking as discussion advances. Technology refers to tools, devices, 
software, hardware, machines, and any combination of, or modification to, them [16-18]. In the construction context, 'technology' refers to tools, equipment, technical methods, specific construction operations, hand tools, devices, specific materials, and novel scaffolding or formwork. In general, 'technology' comprises artifacts, the knowledge of how to make them, and practices of using them [18-21]. Through this lens, a DT can be called technology. Concepts of technology and innovation, and their terminologies, are discussed in the literature [18,22]. Table 1 shows a list of technologies that are relevant to the five main tasks of construction projects, as well as examples. Some technologies, such as DT, can be applied to more than one task in construction. Considering the context of the investigation, a DT can be named as a technology [23-26], system [27-31], concept [28,32-35], innovation [36,37], or paradigm [38-41].

Table 1. Technology types based on different construction tasks, with examples.

\begin{tabular}{|c|c|c|}
\hline $\begin{array}{l}\text { Task-Based } \\
\text { Technologies }\end{array}$ & Examples of Relevant Technologies & $\begin{array}{l}\text { More Information or } \\
\text { Selected Applications }\end{array}$ \\
\hline $\begin{array}{l}\text { (i) office work and } \\
\text { management } \\
\text { technologies }\end{array}$ & $\begin{array}{l}\text { General applications and software that are used for communications and } \\
\text { paperwork, including emails, the cloud, and Intelligent Systems. }\end{array}$ & $\begin{array}{l}\text { iContract [42], artificial } \\
\text { intelligence [43] }\end{array}$ \\
\hline (ii) design and & Building Information Modelling, Geographic Information Systems, virtual & BIM [44], GIS [45], \\
\hline planning technologies & reality (VR), Cybersecurity, Simulations, Big Data and analytics & CyberGIS [46], VR \\
\hline $\begin{array}{l}\text { (iii) production } \\
\text { technologies }\end{array}$ & $\begin{array}{c}\text { 3D Printing (3DP), robotics, Tunnel Boring Machine (TBM), automation, } \\
\text { autonomous haulage system, Digital Twin. }\end{array}$ & $\begin{array}{l}3 \mathrm{DP}[47-49] \\
\text { robotics }[50]\end{array}$ \\
\hline $\begin{array}{l}\text { (iv) job-site vision } \\
\text { technologies }\end{array}$ & $\begin{array}{c}\text { Radio frequency identification (RFID), sensors, Internet of Things (IoT), light } \\
\text { detection and ranging (lidar), laser scanners, cameras for site management, } \\
\text { unmanned aerial systems (UAS), physical progress monitoring, and } \\
\text { productivity, safety, and security. }\end{array}$ & $\begin{array}{l}\text { Lidar applications } \\
{[51-54], \text { UAS }[55,56]}\end{array}$ \\
\hline $\begin{array}{l}\text { (v) dependent } \\
\text { high-tech }\end{array}$ & $\begin{array}{l}\text { Global positioning system (GPS), radar, real-time locating system, remote } \\
\text { controlling devices and diagnostic systems attached or imbedded in heavy } \\
\text { equipment such as graders or cranes. }\end{array}$ & $\begin{array}{l}\text { Remote sensing } \\
\text { applications [57], } \\
\text { Real-time locating } \\
\text { systems [58] }\end{array}$ \\
\hline
\end{tabular}

The concept of DT is new to the literature in built environment disciplines, including smart cities, building, construction, and mining. There exists confusion between advanced applications of some current technologies such as Building Information Modeling (BIM) and DT that may prevent the acceptance of DT as a new concept or practice. The only consensus is that a DT is a digital representation of a physical object [59], but there are more conditions to be satisfied by a DT. The DT concept is initially perceived as useful for monitoring, controlling, or inspecting physical objects such as a vehicle. At the same time, it works in extreme conditions in remote areas where there is nil accessibility for inspection once the project has been launched into space [59]. DTs are expected to have 'self-awareness' [59] and self-optimisation to enable bi-directional conversations and similar controls.

Figure 1 shows the increase in demand for immersive technologies and DT in two separate years. The figure shows that there might be a large market for virtual reality or augmented reality tools. While the market for immersive technologies is growing, DT demand has increased from \$US3.8 billion to \$US36 billion. DT can exploit and articulate the unique capabilities of augmented reality and the IoT device for any user [60]. 


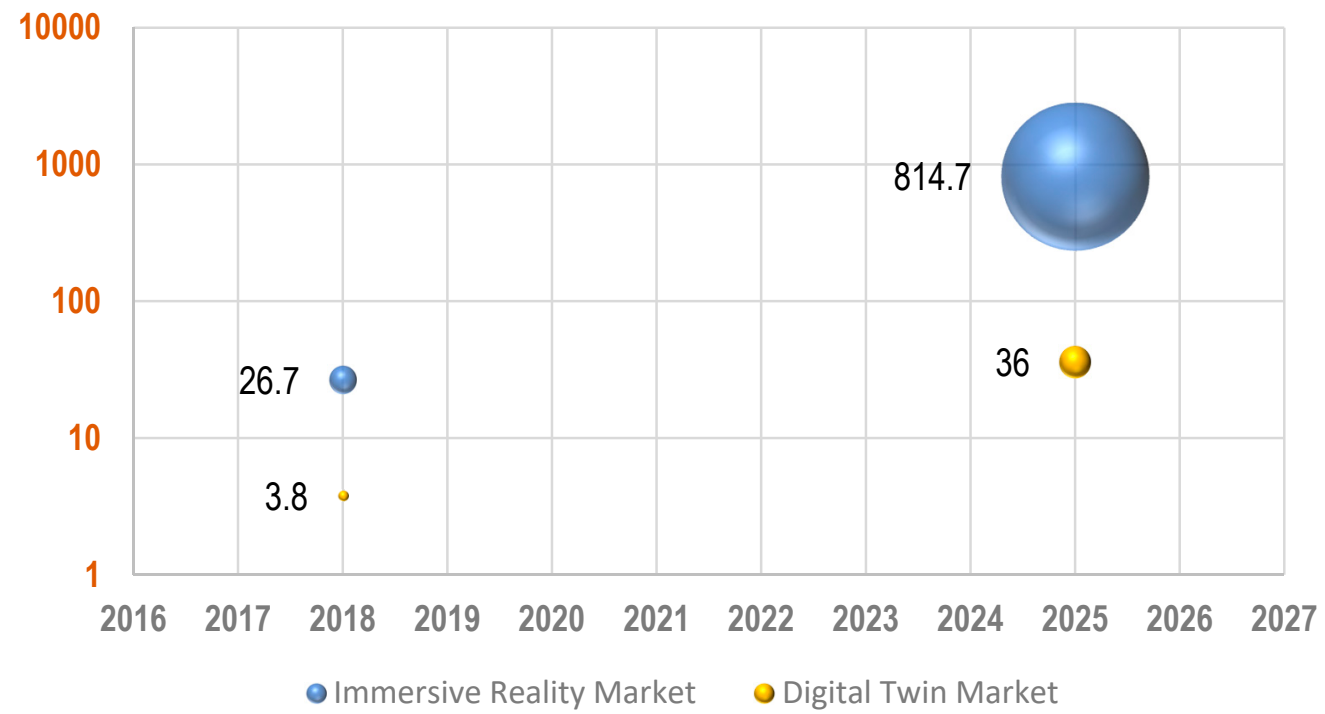

Figure 1. The increase in developing immersive reality and digital twin markers by 2025. Note: units are USD billion.

This paper addresses two main questions. First, what is a DT and how can it be distinguished from previous practices of digital modeling. And second, what sub-topics should be investigated to develop DT further, including DT adoption scenarios for the post-COVID-19 environment.

\section{Scientometric Analysis and Trends}

In order to present the quantitative features of digital twin scientific research and offer an insight into the scholarly publications, this section provides a set of analyses. The literature suggests the use of scientometric analysis to identify emerging trends, as well as evaluating relevant literature. This method is deployed to map scientific knowledge in the selected field and assists scholars to identify the field's challenges or needs. There are examples of extensive quantity analysis in smart home [43]; lean construction [61]; Internet of Things (IoT) [62]; construction delay [63]; Information and Communication Technology (ICT)-assisted disaster management [64]; and additive manufacturing [47]. Figure 2 offers a trend analysis of Google search for DT and its application (see the yellow area). The number of scholarly papers published on DT in Scopus also shows that academia and practitioner attention has risen, with a large increase in the number of scholarly papers indexed in Scopus and Google search in recent years (1536 in 2020).

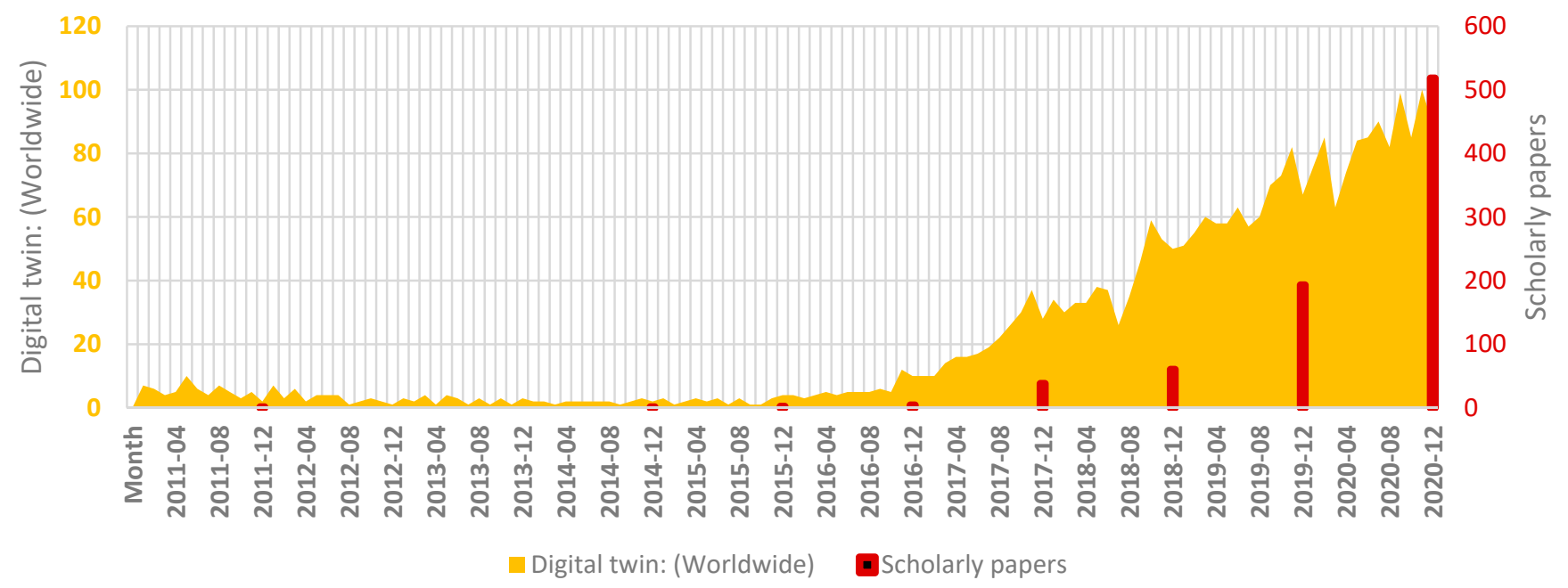

Figure 2. Trend analysis showing an exponential rise in search for the DT topic. 
Figure 3 shows the co-occurrence of keywords used in the DT literature based on Scopus search data. The keyword 'Digital Twin' was used to search within the title, abstract and keyword fields. Search results were refined by applying the year limitation (2011-2020) and by selecting only the journal articles that were published in English. The analysis is based on a minimum of 635 words out of 6877 from the data set of 817 journal papers published in the past decade.

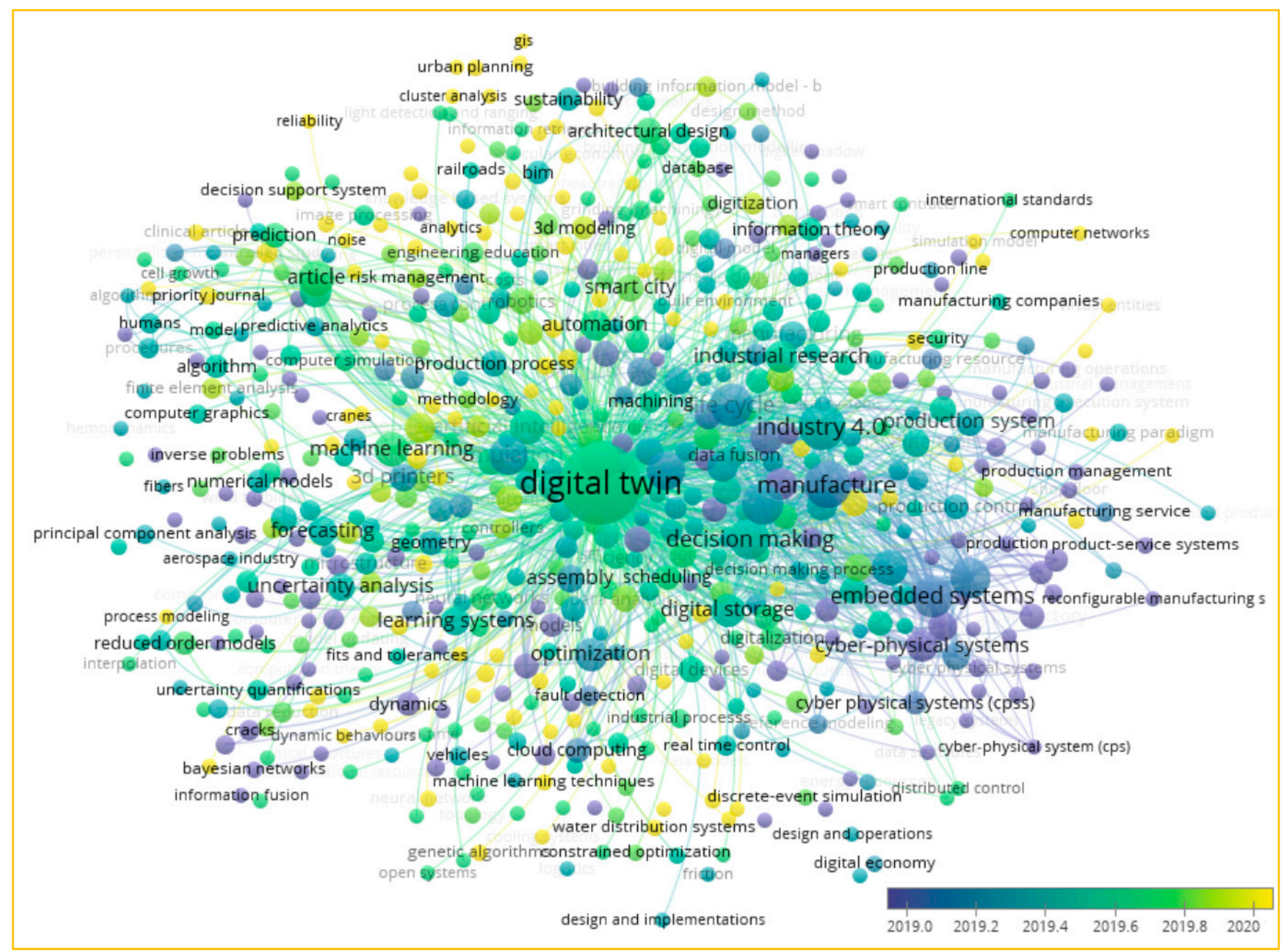

Figure 3. Co-occurrence of keywords in the literature with a minimum of 635 words out of 6877 from the data set of 817 documents published in the past decade (2011 to December 2020).

Figure 4 shows themes that have emerged alongside DT in recent years, such as blockchain and deep learning. It also shows that one of the earliest applications of DT was in manufacturing.

In order to learn from the VR literature, keywords suggested by Khan, et al. [65] were used to identify themes covered previously. Figure 5 shows how the literature is fragmented and that many countries have contributed to developing virtual applications. 


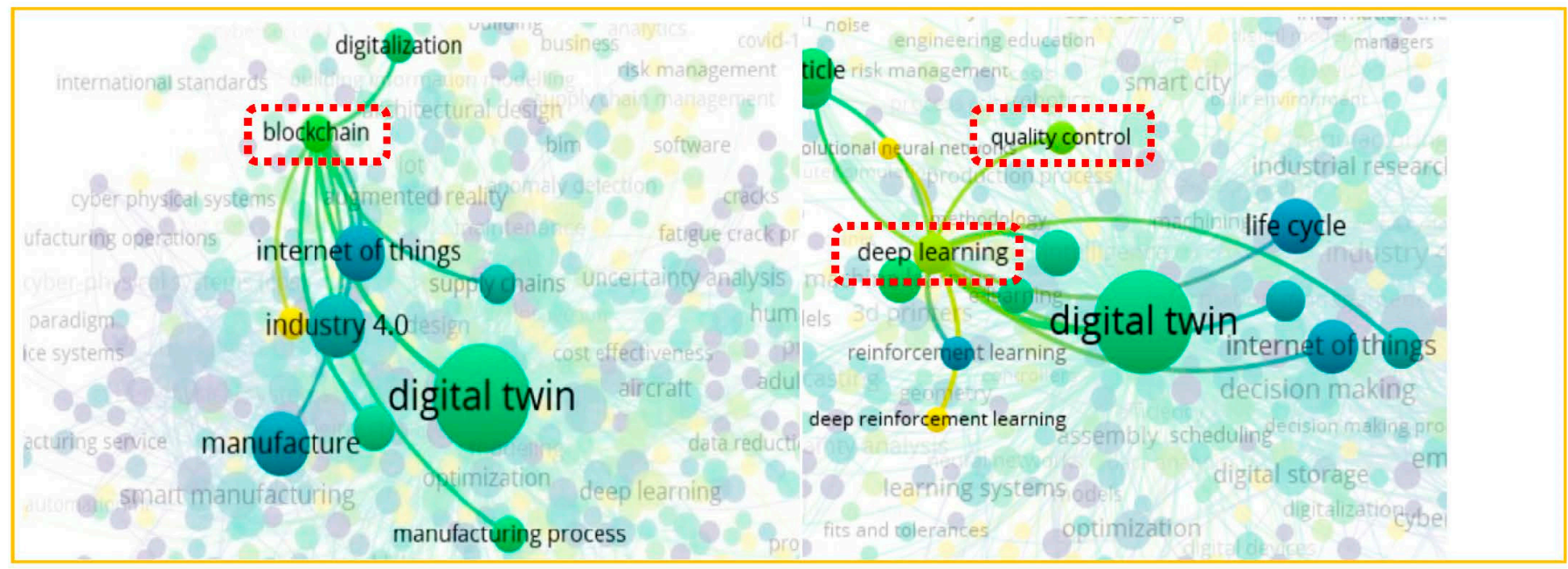

Figure 4. Blockchain, robotics, and deep learning are emerging themes in the DT literature to improve its efficiency.

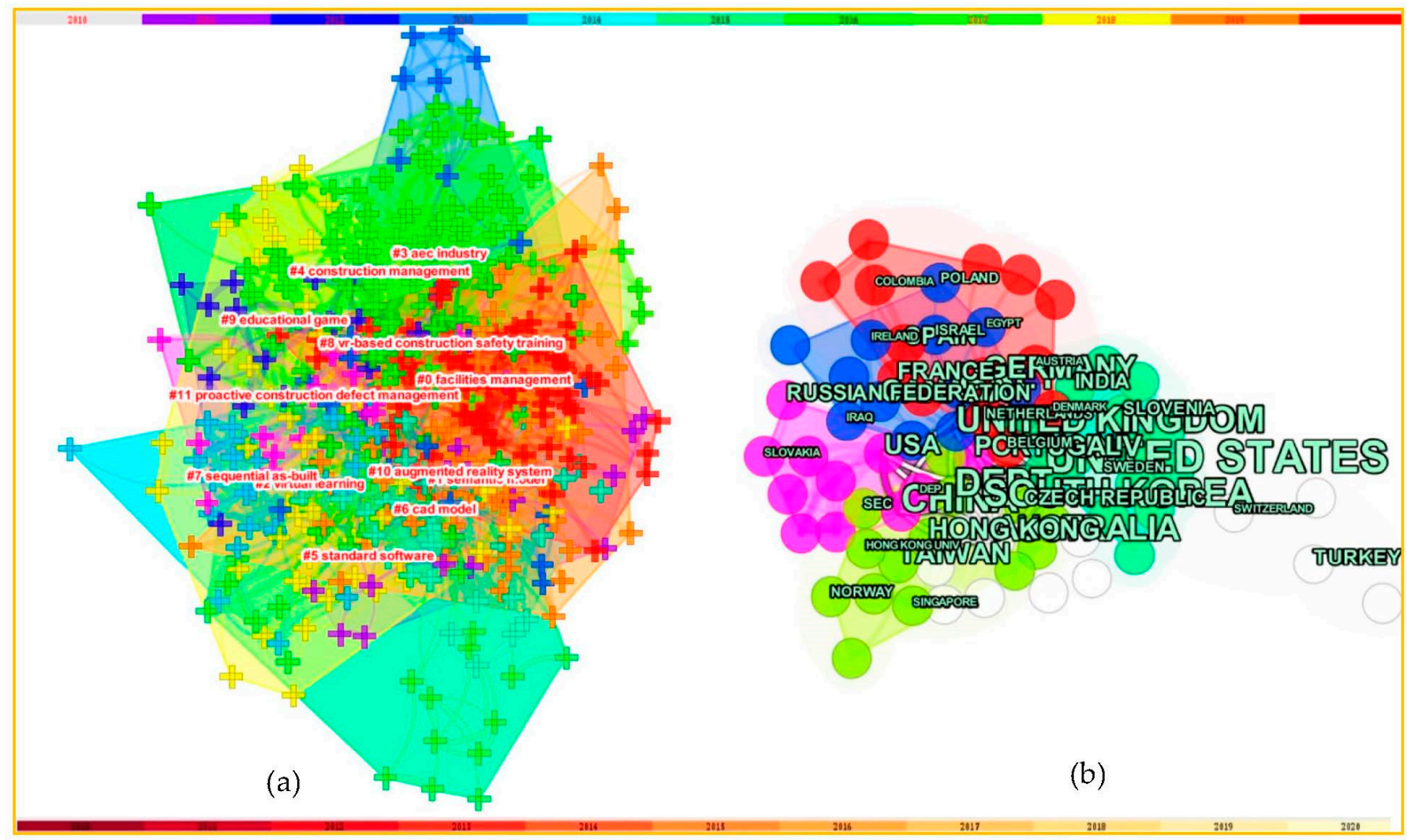

Figure 5. Conceptualised themes and contributions in the VR literature. (a) Visualising the 12 fragmented themes identified; (b) the contribution of different countries in developing VR applications.

Figure 5a shows 12 main themes of VR technologies and their applications in the literature. The search keywords and content review are presented by Khan, Sepasgozar, Liu and $\mathrm{Yu}$ [65]. Applications in the VR dataset were mostly used for educational game and training, defect management, and design objectives. However, the VR literature shows that, as a whole, the body of knowledge for the built environment, including construction, lacks direction. Such objectives could be improved by developing DT with the utilisation of VR or XR; however, it now exhibits a gap in the literature. Figure $5 b$ shows that some regions and collaborations between researchers from these countries extended the body of literature. These regions include, but are not limited to, the United States, Britain, 
France, Germany, China, Hong Kong, Turkey, Taiwan, Poland, and Singapore. However, the literature shows that more investigations are needed in other countries, particularly developing nations, to ensure that their industries can embrace and enhance the use of AR and VR.

\section{Distinction between Digital Shadow and Digital Twin}

Very few papers referred to digital models (e.g., BIM) and DT as similar concepts or used them interchangeably $[33,66,67]$. However, there is a significant difference between $\mathrm{DT}$ and current digital 3D models and 3D systems. If a virtual model represents the physical model only, with one-way data flow, this is considered to be a Digital Shadow (DS) [66]. Figure 6 shows the one-way data flow from a digital model to a physical entity of a tower crane in a DS. However, in a DT, both the virtual and physical entities should communicate with each other. A decade ago, an early definition of DT was considered to be an integration of the multi-physics of a vehicle with probabilistic simulation that mirrored its life [68]. Later in the literature, the vehicle was replaced with a machine, factory, processes, labour, and many other physical entities [69], and the replication of this concept in many other disciplines is growing.

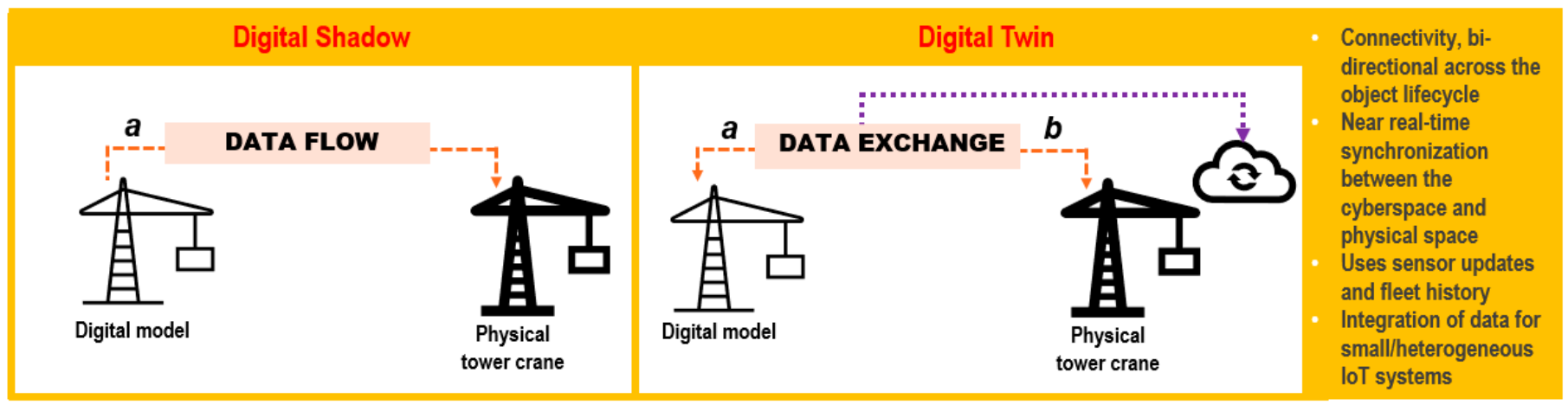

Figure 6. Schematic visualization of both 'one-way' and 'bi-directional' data flow for distinguishing DS from DT.

Figure 6 shows the bi-directional data flow between digital model and tower crane in a proposed DT. Digital Twin (DT) emphasises bi-directional conversations [60,70,71], and data flow is automated [15]. This means that every digital representative of a physical object cannot be considered to be a DT [15].

The current DT definitions stress that the digital entity reflects the geometric dimensions, shapes, and other attributes of physical objects [72]. The DT should also be able to map the logic and rules used in the process or behaviour of the physical entities [73]. Furthermore, the DT should be able to codify the data and reflect past, current, and future predictions of the physical entity, including assets or processes.

In order to provide greater insight into the definition of DT, a set of 21 definitions published in the literature from 2012 [68] to 2019 [35,38] was analysed. Figure 7 shows the outcome of this analysis, providing an understanding of the most frequent keyword and unique terms used to define a DT. Figure 7 shows that 'digital', 'twinning', 'physical', and 'modeling' have the highest frequency greater than 12 and the weighted percentage above 3.23 among all stemmed words used in definitions. However, other keywords used for defining a DT are real-time possibility, system, simulation, asset, and data. The key characteristics of DT as mentioned in the definitions are: fidelity [74,75], real-time control [76], real-time optimisation, virtual replica [60,77], dynamic digital replica [78], and dynamic bi-directional $[35,79]$. 


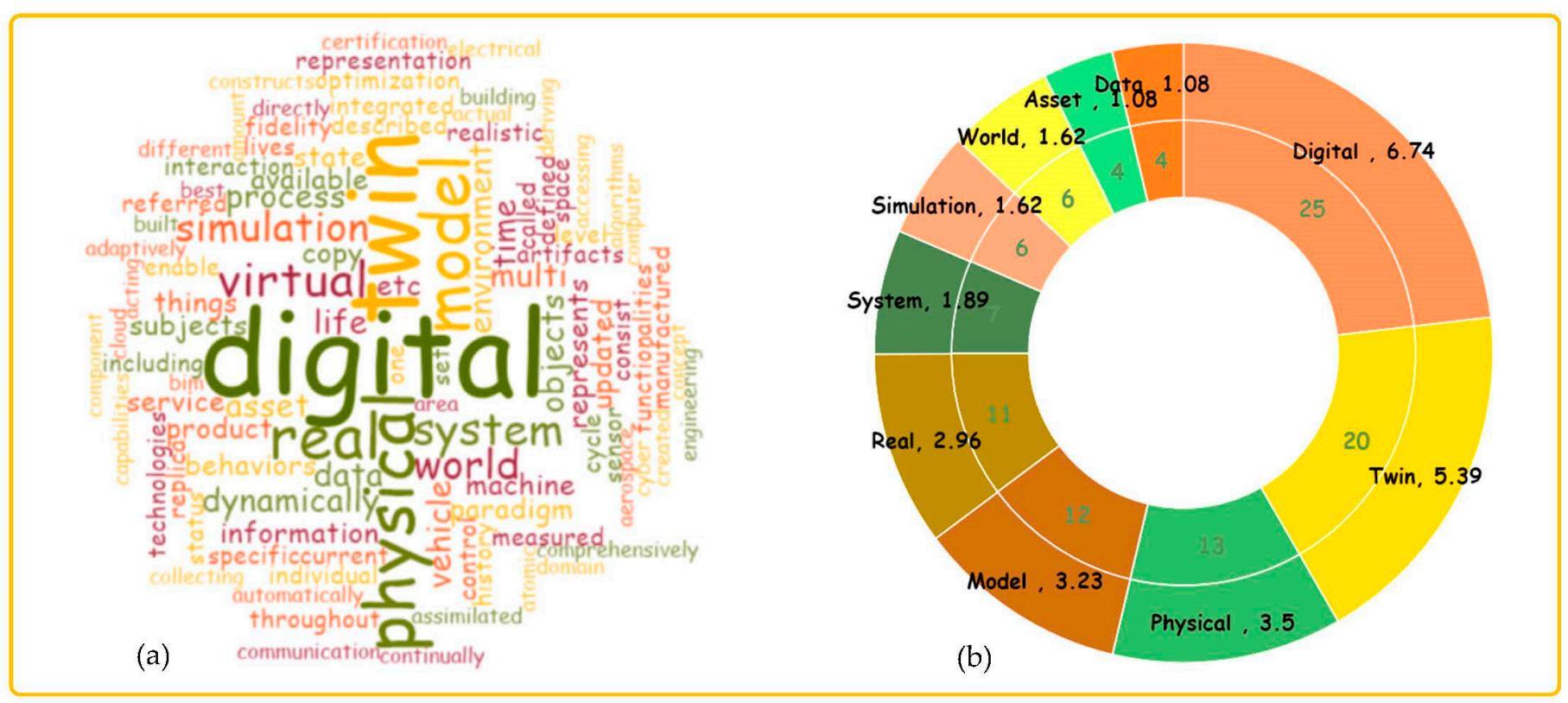

Figure 7. The analysis of 21 key definitions of DT published between 2012 and 2019. (a) Visualisation of the word frequency; (b) the count value for high-frequency words and the weighted percentage among all the stemmed words used in definitions.

In recent years, DT has also been divided into different types, as shown in Figure 8. The digital twin prototype (DTP) refers to an artifact's prototype, including the information required to represent the virtual model. This can be developed for aircraft, processes, and operations [80]. It may refer to a rich BIM created by the designer before the construction phase and used to create a building, which is why the DT is sometimes misunderstood as BIM $[67,81]$. However, the rest of DT characterisation, such as bi-directional information flow during the lifecycle, was ignored here. The digital twin instance (DTI) refers to each individual instance of the object where it is created, including Geometric Dimensioning and Tolerancing (GD\&T) [82-84]. The DT aggregate/environment (DTD/E) refers to multi-domain applications for employing the DT to meet various needs [82].

Digital twin aggregate/environment (DTA/E) including technology, human and process

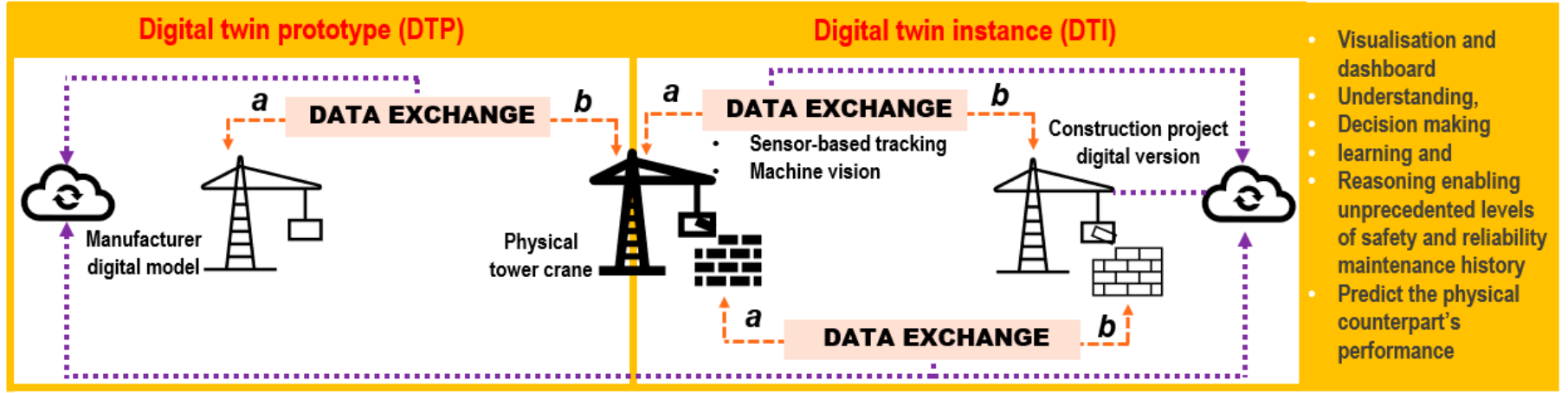

Figure 8. Schematic of the DT, including different dimensions of the DT. A shared DT between stakeholders such as manufacturers and construction contractors is necessary.

\section{State of Play and an Agenda for Future}

This section discusses the state of play and suggests important directions for further developing the DT and ensuring it is widely accepted. The DT offers a variety of functionality to practitioners in various sectors. The heavy-equipment manufacturing and construction industries are both concerned about the performance, durability, maintenance, safety, and productivity of equipment. While manufacturers develop many simulations and models for equipment, the end-user has less access, knowledge, and skill to create or 
use such complex simulation models. Digital versions of the equipment will help end-users to achieve their daily goals on hazardous or congested construction sites. Figure 9 shows an example of an excavator digital twin on a small scale. It was developed to simulate and learn from excavation, so that such models could help the end-user control or monitor equipment remotely.
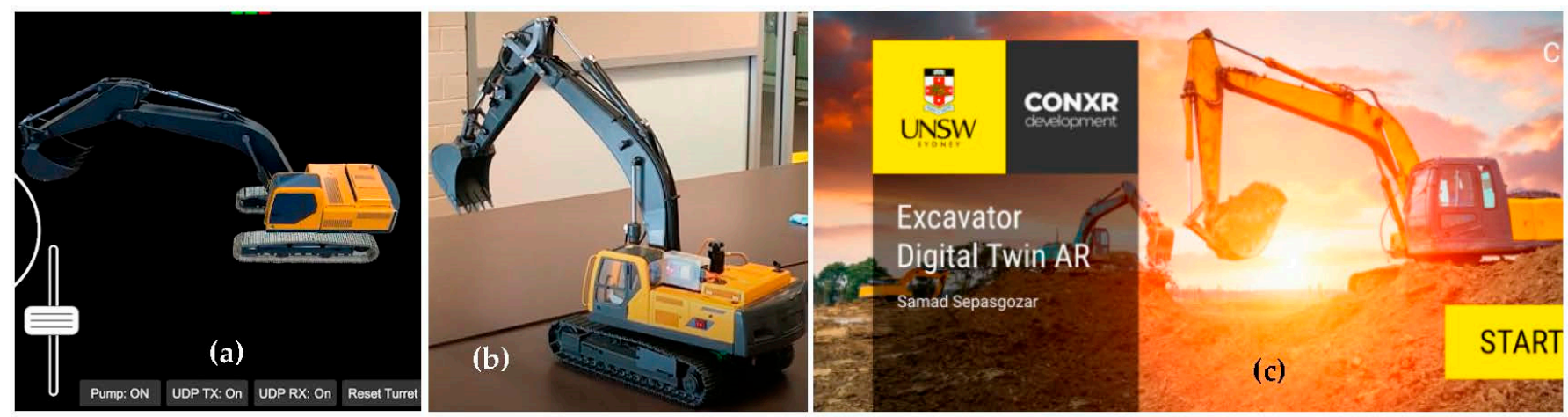

Figure 9. Digital and physical objectives in outdoor experimentation. (a) augmented model; (b) physical excavator model; (c) the DT application entrance.

In this instance, the excavator can be controlled in two ways. The bi-directional data exchange helps the end-user run the equipment from a distance or provide a decentralised platform for collaboration. One of the remote controls directly communicates with the excavator. A tablet with an augmented model of the excavator can also be used. Any change or control made via the augmented model can be transferred to the physical system.

DT technology enables practitioners and managers to improve resilience, manage risk, and save energy and resources. The literature is still embryonic, and many issues or gaps should be addressed before DT is widely accepted in the industry. One recognised need is for constant or near-real-time data exchange using a secure, reliable, and high-speed network. There is no consensus on specific technical components, protocols, or tools to create a DT or define it as a universal technology [35]. However, the literature suggests that the various types of tools used for DT are as listed, but not limited to:

- communication or wireless technologies used for DT, such as the fourth/fifth-generation cellular network (4/5G), NB-IoT, Sigfox, Bluetooth, LoRaWAN, ZigBee, Z-Wave, GSM, 802.11 ah, 802.11 n, LTE-M, BLE, and WirelessHART [35];

- layer protocols applications used for DT, such as HTTP, MQTT, mDNS, CoAP, XMPP, DDS, AMQP, and OPC UA [35];

- recent platforms such as Predix (GE Digital) for data analytics and industrial monitoring; MindSphere (Siemens) for storing operational data; ThingWorx; Watson IoT Platform; Ditto; Azure Digital Twins [85];

Advanced technologies such as wireless sensor networks, industrial AI, blockchain, and transfer learning algorithms must be appropriately integrated and used to improve the functionality and capability of DT in various SCEC sectors. Table 2 shows the application of different tools to DT developers. Based on the DT's capability, the following directions are recommended for future studies in the SCEC context.

The main elements of a useful DT are smart sensors, actuators, or controllers. At the same time, major potential issues in DT design would include data synchronisation, high latency, high energy consumption, security, and privacy holes. While there are few case studies in the literature, the market offers different tools to develop DTs. General Electric (GE) offers Predix, a platform that enables asset connectivity and edge-to-cloud data processing. Predix helps practitioners to connect assets and IoT data, receive alerts for industrial events, and regularly monitor the conditions of each process $[15,86]$. Other platforms and tools in the market can be used to develop DTs, as mentioned in Table 2. 
One major current challenge transferring big data for real-time controls and immediate scenario optimisations should be addressed in the future with the availability of 5G. This will facilitate the data exchange and required connectivity [87]. Another challenge to be addressed is disconnection due to network gaps in the field [88]. Future work should focus on designing and examining innovative DTs to present useful benchmarks for practitioners and scholars [34]. The following research questions are put forward for investigation:

Table 2. State of play and suggestions for future investigations and application development.

\begin{tabular}{|c|c|c|}
\hline Direction & State of Play-Key Tools or Limitations & Suggestions for Future Applications or Investigations \\
\hline $\begin{array}{l}\text { Technology } \\
\text { development }\end{array}$ & $\begin{array}{c}\text { Predix (GE Digital) for data analytics and } \\
\text { industrial monitoring; MindSphere (Siemens) for } \\
\text { storing operational data; ThingWorx; Watson IoT } \\
\text { Platform; Ditto; Ansys simulation platform [89]; } \\
\text { Azure Digital Twins }\end{array}$ & $\begin{array}{l}\text { Develop an autonomous resilient response to breakdown } \\
\text { and failures in systems or processes [85]; response to } \\
\text { unexpected incidents before occurring [90] Address } \\
\text { network gaps in the field and underground sites }\end{array}$ \\
\hline $\begin{array}{l}\text { Connectivity, } \\
\text { data mapping, } \\
\text { and data fusion }\end{array}$ & $\begin{array}{l}\text { The use of individual technologies such as data } \\
\text { mapping tools [66]; fuzzy sets, rule-based } \\
\text { reasoning, and intelligent algorithms [91]; 5G; } \\
\text { wireless sensor networks, industrial AI; } \\
\text { blockchain; and transfer learning; Beacons and } \\
\text { RTLS (real-time locating system) [58]; and RFID } \\
\text { (radio-frequency identification) [92] for collecting } \\
\text { motion data from mobile production equipment } \\
\text { such as cranes and excavators. }\end{array}$ & $\begin{array}{l}\text { Collect quality motion data from sites and optimise in } \\
\text { near real-time; apply advanced analytics methods to } \\
\text { enhance self-configure, self-adapt, and self-learning } \\
\text { capability of the DT [85]; integrate and connect to BIM } \\
\text { [44,48]; collect multi-modal (e.g., radar, laser, or lidar), } \\
\text { multi-source and homogeneous data, apply multi-actor } \\
\text { game-theory decision algorithms considering dynamic } \\
\text { factors [93]; connecting energy networks; decentralised } \\
\text { digital twin models [94] and integration with blockchain. }\end{array}$ \\
\hline $\begin{array}{l}\text { Application } \\
\text { identification, } \\
\text { learning, and } \\
\text { decision- } \\
\text { making }\end{array}$ & $\begin{array}{l}\text { Earth-DT with the integration of the human } \\
\text { dimensions for achieving SDGs [95]; further } \\
\text { development of disaster city-DT [93,96] for } \\
\text { emergency management; DT for smart city [96,97]; } \\
\text { optimise life cycle management }[33,81] \text {; smart } \\
\text { campus' DT for comfort assessment [98]; } \\
\text { DT-Enabled Energy Management [99]. }\end{array}$ & $\begin{array}{l}\text { Apply optimisation scenarios for decision-making [85]. } \\
\text { Develop autonomous resilience control; apply } \\
\text { decision-support tools. }\end{array}$ \\
\hline $\begin{array}{l}\text { Readiness } \\
\text { investigations }\end{array}$ & $\begin{array}{l}\text { Advantages, drivers, and barriers of } \\
\text { technology acceptance. }\end{array}$ & $\begin{array}{l}\text { Develop novel digital business models for post-COVID-19 } \\
\text { based on DT; Shared technology and process for the } \\
\text { circular economy. }\end{array}$ \\
\hline
\end{tabular}

(a) Future directions on enabling technologies for modeling and simulation should address the following:

- How different virtual entities or systems, including BIM (e.g., 6D BIM) and GIS, can be integrated with a two-way conversation between them in a project ecosystem that considers all stakeholders (Lack of a common framework for creating digital twin models should be addressed).

- How simulation and optimisation can be done in near real-time.

(b) Future directions on data fusion and integration should address the following:

- How intelligence-enabling technologies (e.g., IoT, CPS, DT, big data analytics) can be integrated to improve smart construction processes or smart cities by automating motion data collection. How virtual and real fusion optimisation processes can be improved with regard to digital mode richness.

- How the combinations of mechanisms, accuracy, quality, and real-time optimisation of data analysis can be improved.

(c) Future directions on interaction and collaboration can address the following:

- How the generated data and digital entity can be shared among various untrusted stakeholders or sub-contractors during a project's life cycle, considering human interactions (e.g., different types of human-machine, machine-machine, and human-computer-machine interactions). 
- How cyber-physical systems (CPS) can be used to develop a self-organising system for different tasks by utilising intelligence-based mechanisms that enable decentralisation and collaboration.

(d) Future directions on DT service and implementation can address the following:

- Technical or managerial barriers and potential solutions to successfully implement a DT in a company. The extent to which companies different in size (e.g., small, medium-sized, and large) are ready to apply innovative DTs for various operational or managerial tasks.

- How the DT and data ownership, privacy, level of accessibility by each stakeholder, and security issues can be resolved using blockchain or other approaches.

Table 2 shows that one main task for utilising a DT is connectivity and data fusion, which mainly refers to preprocessing big data, data mining, and real-time optimisation [91]. The data can be generated from physical entities and many associated applications, which can make data format, type, and reliable communication between all respective devices and entities challenging. Connectivity is a core element in smart systems such as smart cities or construction that should be improved as a critical requirement of DT [46]. This can help to improve and develop the designed system to enable the following tasks or processes: integrity management, regular risk-based inspection, automated optimisation of construction operations (e.g., excavation strategies), enhancing maintenance and safety, integrating and exchanging data with intelligence contract [42,100], preventing operation risks, optimising energy consumption [101], and enabling energy management [99]. Another critical concern in several sectors that DT can improve is Prognostic Health Management (PHM), as shown in Figure 10. Among different maintenance strategies, such as reactive, preventive, condition-based, predictive, and prescriptive maintenance, the last two approaches may benefit most from the digital concepts [66]. Recently, a DT was recommended for sustainability [102]. This can be achieved by developing sustainable intelligence sub-systems, including equipment, services, construction tasks, and activities.

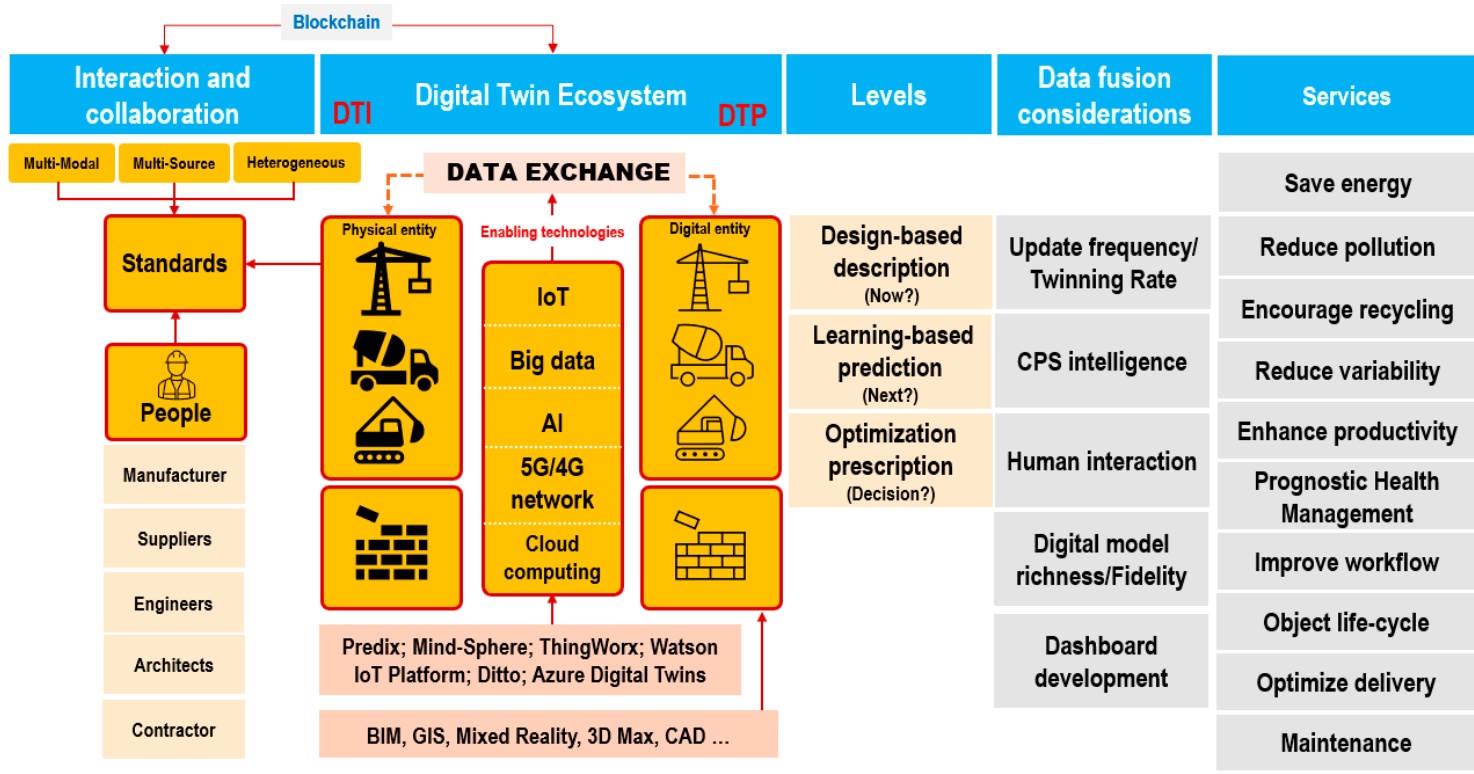

Figure 10. DT ecosystem including a taxonomy of DT tools, levels, and data fusion considerations. DTI: digital twin instance; DTP: digital twin prototype; CPS: cyber-physical system.

A DT can be used to 'learn' and suggest new scenarios before building an object, manufacturing tools and heavy equipment, creating the asset, developing a construction process, and planning for developing other smart cities [15]. Figure 10 defines different 'levels' for a DT, such as description, prediction, and prescription capability. The main 
value of learning with the combination of predictive and prescriptive DT processes lies in reducing downtime, breakdowns, costs, energy waste, and in achieving Sustainable Development Goals (SDGs). Such learning advantages are in line with DT's capability for simulation, monitoring, lifecycle assessment, sensing, optimisation, and prediction.

In SCEC, the key purpose of a DT is to improve productivity, sustainability, safety, and/or achieve other objects of an organisation or project. However, the main obstacle to developing a DT for such purposes is the system architecture and reliability of the DT [35]. Since a DT's key element is data exchange, the integration of the blockchain with the DT would result in decentralisation, improved security, and immutable data exchange among various stakeholders. Blockchain can enhance construction companies' digital values and facilitate smart monetary transactions in a smart environment [103]. At the same time, the need to save the earth by reducing carbon footprints, preventing rapid climate change, and increasing sustainability led united nations to develop and present a vital agenda and implementation plan for archiving the SDGs. Current smart systems such as smart homes should be redesigned with consideration to DT's capability $[43,104]$.

The possibility of using diverse wearable sensors, smartphones, tablets, and other intelligent sensors may accelerate the acceptance of DT in different contexts. The diversity of these devices may present challenges of data granularity, interoperability, the heterogeneity of information, multi-source information, and many attributes such as data format, data sampling intervals, data security, and trust. These will need to be resolved to increase industry readiness for utilising the DT. For example, the most common source of data is images or videos, and recently handheld mobile scanners are widely available to collect point cloud datasets. However, collecting point cloud data frequently from the built environment and construction sites can be expensive. Previous studies have examined different tools for point cloud data acquisition and suggested that handheld tools are more convenient and efficient, depending on the accuracy required [52,105-108]. Figure 11 shows how both images and point clouds are collected from outdoor areas of a light rail construction project. A handheld tool was used for data acquisition, and Sepasgozar, Forsythe and Shirowzhan [106] discussed the advantages of the handheld scanner in comparative experimentation. Using handheld mobile scanners helps practitioners to collect data easily and more quickly than using terrestrial scanners. Providing a comprehensive image of the built environment can be possible if a multi-modal data acquisition method is adopted, although it can be technically challenging. This approach was used in other disciplines, such as modern automobiles [109].

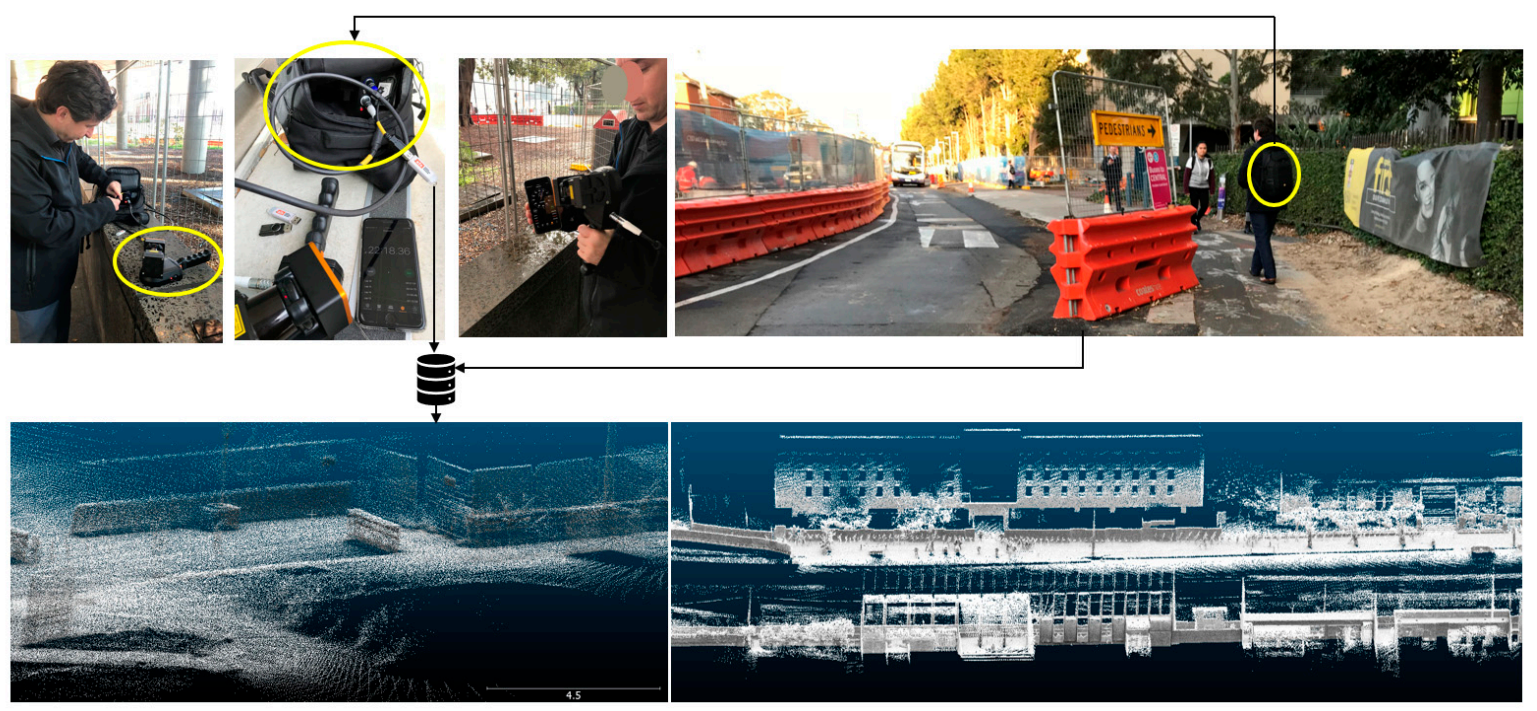

Figure 11. A case of multi-modal and multi-source data acquisition experimentation, including images and point cloud data using a camera and a selected handheld scanner from a light rail construction project. 


\section{Conclusions}

This paper has reviewed the current DT literature and discerned that it is embryonic and developing in two main directions. One direction focuses mainly on the definition, defining dimensions and functionalities of DT for different contexts. Another direction focuses on extending current DS practices, assuming it is digital twinning. The missing core element of these practices is the bi-directional flow of data between digital and physical entities.

The position of this paper was to differentiate DT from other modeling practices, and to distinguish the DT concept from the digital shadow (representing a physical model with a one-way data flow). The DT concept was discussed, along with presenting the case of an excavator DT that can be considered as capable of replicating in different contexts.

As with many studies that focus on technology development and applications, the current emerging literature on DTs focuses on SDGs and relevant concepts. This study suggests that the implementation of SDGs should be considered in the development of the DT.

The value of this study lies in making a crucial distinction between DT and DS technologies and suggesting a set of directions for further investigation.

Funding: This research received no external funding.

Data Availability Statement: The data presented in this study are available on request from the corresponding author.

Conflicts of Interest: The author declare no conflict of interest.

\section{References}

1. Hotový, M. Dynamic model of implementation efficiency of Building Information Modelling (BIM) in relation to the complexity of buildings and the level of their safety. In Proceedings of the MATEC Web of Conferences, Les Ulis, France, 22 January 2018; p. 01010.

2. Starr, C.W.; Saginor, J.; Worzala, E. The rise of PropTech: Emerging industrial technologies and their impact on real estate. J. Prop. Invest. Financ. 2020, 39. [CrossRef]

3. García de Soto, B.; Agustí-Juan, I.; Joss, S.; Hunhevicz, J. Implications of Construction 4.0 to the workforce and organizational structures. Int. J. Constr. Manag. 2019, 1-13. [CrossRef]

4. Osunsanmi, T.O.; Aigbavboa, C.O.; Oke, A.E.; Liphadzi, M. Appraisal of stakeholders' willingness to adopt construction 4.0 technologies for construction projects. Built Environ. Proj. Asset Manag. 2020, 10, 547-565. [CrossRef]

5. Boton, C.; Rivest, L.; Ghnaya, O.; Chouchen, M. What is at the Root of Construction 4.0: A systematic review of the recent research effort. Arch. Comput. Methods Eng. 2020, 1-20. [CrossRef]

6. Sepasgozar, S.M. Digital technology utilisation decisions for facilitating the implementation of Industry 4.0 technologies. Constr. Innov. 2020. [CrossRef]

7. Lööw, J.; Abrahamsson, L.; Johansson, J. Mining 4.0-The impact of new technology from a work place perspective. Min. Metall. Explor. 2019, 36, 701-707. [CrossRef]

8. Faz-Mendoza, A.; Gamboa-Rosales, N.; Medina-Rodríguez, C.; Casas-Valadez, M.; Castorena-Robles, A.; López-Robles, J. Intelligent processes in the context of Mining 4.0: Trends, research challenges and opportunities. In Proceedings of the 2020 International Conference on Decision Aid Sciences and Application (DASA), Sakheer, Kingdom of Bahrain, 8-9 November 2020; pp. 480-484.

9. Ciolacu, M.; Tehrani, A.F.; Beer, R.; Popp, H. Education 4.0-Fostering student's performance with machine learning methods. In Proceedings of the 2017 IEEE 23rd International Symposium for Design and Technology in Electronic Packaging (SIITME), Constanta, Romania, 26-29 October 2017; pp. 438-443.

10. Ramirez-Mendoza, R.A.; Morales-Menendez, R.; Iqbal, H.; Parra-Saldivar, R. Engineering Education 4.0: Proposal for a new Curricula. In Proceedings of the 2018 IEEE Global Engineering Education Conference (EDUCON), Canary Islands, Spain, 18-20 April 2018; pp. 1273-1282.

11. Hussin, A.A. Education 4.0 made simple: Ideas for teaching. Int. J. Educ. Lit. Stud. 2018, 6, 92-98. [CrossRef]

12. Lin, W.; Low, Y.; Chong, Y.; Teo, C. Integrated cyber physical simulation modelling environment for manufacturing 4.0. In Proceedings of the 2018 IEEE International Conference on Industrial Engineering and Engineering Management (IEEM), Bangkok, Thailand, 16-19 December 2018; pp. 1861-1865.

13. Caiado, R.G.G.; Scavarda, L.F.; de Mattos Nascimento, D.L.; Ivson, P.; Cunha, V.H.C. A Maturity Model for Manufacturing 4.0 in Emerging Countries. In Proceedings of the International Conference on Production and Operations Management Society, Operations Management for Social Good, Rio de Janiero, Brazil, 10-12 December 2012; p. 393. 
14. Hernandez, J.D.; Cespedes, E.S.; Gutierrez, D.A.; Sanchez-Londoño, D.; Barbieri, G.; Abolghasem, S.; Romero, D.; Fumagalli, L. Human-Computer-Machine Interaction for the Supervision of Flexible Manufacturing Systems: A Case Study. In Proceedings of the 21st IFAC (International Federation of Automatic Control) World Congress 2020, Berlin, Germany, 12-17 July 2020.

15. Fuller, A.; Fan, Z.; Day, C.; Barlow, C. Digital twin: Enabling technologies, challenges and open research. IEEE Access 2020, 8, 108952-108971. [CrossRef]

16. Arditi, D.; Kale, S.; Tangkar, M. Innovation in Construction Equipment and Its Flow into the Construction Industry. J. Constr. Eng. Manag. 1997, 123, 371-378. [CrossRef]

17. Skibniewski, M.J.; Zavadskas, E.K. Technology Development in Construction: A Continuum From Distant Past into the Future. J. Civ. Eng. Manag. 2013, 19, 136-147. [CrossRef]

18. Sepasgozar, S.M.E.; Loosemore, M.; Davis, S.R. Conceptualising information and equipment technology adoption in construction A critical review of existing research. Eng. Constr. Archit. Manag. 2016, 23, 158-176. [CrossRef]

19. MacKenzie, D.; Wajcman, J. The Social Shaping of Technology; Open University Press: Buckingham, UK, 1999.

20. Bijker, W.E. How Is Technology Made?-That Is the Question! Camb. J. Econ. 2010, 34, 63-76. [CrossRef]

21. Sepasgozar, S.M.; Davis, S. Construction Technology Adoption Cube: An Investigation on Process, Factors, Barriers, Drivers and Decision Makers Using NVivo and AHP Analysis. Buildings 2018, 8, 74. [CrossRef]

22. Sepasgozar, S.M.; Davis, S. Digital Construction Technology and Job-site Equipment Demonstration: Modelling Relationship Strategies for Technology Adoption. Buildings 2019, 9, 158. [CrossRef]

23. Liu, J.; Zhou, H.; Liu, X.; Tian, G.; Wu, M.; Cao, L.; Wang, W. Dynamic evaluation method of machining process planning based on digital twin. IEEE Access 2019, 7, 19312-19323. [CrossRef]

24. Zhuang, C.; Liu, J.; Xiong, H.; Ding, X.; Liu, S.; Weng, G. Connotation, architecture and trends of product digital twin. Comput. Integr. Manuf. Syst. 2017, 23, 753-768.

25. Wang, K.-J.; Lee, T.-L.; Hsu, Y. Revolution on digital twin technology-A patent research approach. Int. J. Adv. Manuf. Technol. 2020, 107, 4687-4704. [CrossRef]

26. Halenar, I.; Juhas, M.; Juhasova, B.; Borkin, D. Virtualization of production using digital twin technology. In Proceedings of the 2019 20th International Carpathian Control Conference (ICCC), Kraków-Wieliczka, Poland, 26-29 May 2019; pp. 1-5.

27. Kong, T.; Hu, T.; Zhou, T.; Ye, Y. Data construction method for the applications of workshop digital twin system. J. Manuf. Syst. 2021, 58, 323-328. [CrossRef]

28. Haag, S.; Anderl, R. Digital twin-Proof of concept. Manuf. Lett. 2018, 15, 64-66. [CrossRef]

29. He, B.; Cao, X.; Hua, Y. Data fusion-based sustainable digital twin system of intelligent detection robotics. J. Clean. Prod. 2021, 280, 124181. [CrossRef]

30. Liu, L.; Du, H.; Wang, H.; LIU, T. Construction and application of digital twin system for production process in workshop. Comput. Integr. Manuf. Syst. 2019, 25, 1536-1545.

31. Zhang, C.; Xu, W.; Liu, J.; Liu, Z.; Zhou, Z.; Pham, D.T. A reconfigurable modeling approach for digital twin-based manufacturing system. Procedia CIRP 2019, 83, 118-125. [CrossRef]

32. Vachálek, J.; Bartalský, L.; Rovný, O.; Šišmišová, D.; Morháč, M.; Lokšík, M. The digital twin of an industrial production line within the industry 4.0 concept. In Proceedings of the 2017 21st International Conference on Process Control (PC), Štrbské Pleso, Slovakia, 6-9 June 2017; pp. 258-262.

33. Kritzinger, W.; Karner, M.; Traar, G.; Henjes, J.; Sihn, W. Digital Twin in manufacturing: A categorical literature review and classification. IFAC-PapersOnLine 2018, 51, 1016-1022. [CrossRef]

34. Jones, D.; Snider, C.; Nassehi, A.; Yon, J.; Hicks, B. Characterising the Digital Twin: A systematic literature review. CIRP J. Manuf. Sci. Technol. 2020, 29, 36-52. [CrossRef]

35. Liu, M.; Fang, S.; Dong, H.; Xu, C. Review of digital twin about concepts, technologies, and industrial applications. J. Manuf. Syst. 2020. [CrossRef]

36. Susila, N.; Sruthi, A.; Usha, S. Impact of cloud security in digital twin. In Advances in Computers; Elsevier: Amsterdam, The Netherlands, 2020; Volume 117, pp. 247-263.

37. Augustine, P. The industry use cases for the digital twin idea. In Advances in Computers; Elsevier: Amsterdam, The Netherlands, 2020; Volume 117, pp. 79-105.

38. Wang, P.; Yang, M.; Peng, Y.; Zhu, J.; Ju, R.; Yin, Q. Sensor control in anti-submarine warfare-A digital twin and random finite sets based approach. Entropy 2019, 21, 767. [CrossRef]

39. Glaessgen, E.; Stargel, D. The digital twin paradigm for future NASA and US Air Force vehicles. In Proceedings of the 53rd AIAA/ASME/ASCE/AHS/ASC Structures, Structural Dynamics and Materials Conference 20th AIAA/ASME/AHS Adaptive Structures Conference 14th AIAA, Honolulu, HI, USA, 23-26 April 2012; p. 1818.

40. Raj, P.; Evangeline, P. The Digital Twin Paradigm for Smarter Systems and Environments: The Industry Use Cases; Academic Press: Cambridge, MA, USA, 2020.

41. Aydemir, H.; Zengin, U.; Durak, U. The Digital Twin Paradigm for Aircraft Review and Outlook. In Proceedings of the AIAA Scitech 2020 Forum, Orlando, FL, USA, 6-10 January 2020; p. 0553.

42. McNamara, A.J.; Sepasgozar, S.M. Intelligent contract adoption in the construction industry: Concept development. Autom. Constr. 2021, 122, 103452. [CrossRef] 
43. Sepasgozar, S.; Karimi, R.; Farahzadi, L.; Moezzi, F.; Shirowzhan, S.; M Ebrahimzadeh, S.; Hui, F.; Aye, L. A Systematic Content Review of Artificial Intelligence and the Internet of Things Applications in Smart Home. Appl. Sci. 2020, 10, 3074. [CrossRef]

44. Shirowzhan, S.; Sepasgozar, S.M.E.; Edwards, D.J.; Li, H.; Wang, C. BIM compatibility and its differentiation with interoperability challenges as an innovation factor. Autom. Constr. 2020, 112, 103086. [CrossRef]

45. Shirowzhan, S.; Trinder, J.; Osmond, P. New Metrics for Spatial and Temporal 3D Urban Form Sustainability Assessment Using Time Series Lidar Point Clouds and Advanced GIS Techniques. In Urban Design; IntechOpen: London, UK, 2019. [CrossRef]

46. Shirowzhan, S.; Tan, W.; Sepasgozar, S.M. Digital Twin and CyberGIS for Improving Connectivity and Measuring the Impact of Infrastructure Construction Planning in Smart Cities; Multidisciplinary Digital Publishing Institute: Basel, Swittserland, 2020; Volume 9. [CrossRef]

47. Sepasgozar, S.M.; Shi, A.; Yang, L.; Shirowzhan, S.; Edwards, D.J. Additive Manufacturing Applications for Industry 4.0: A Systematic Critical Review. Buildings 2020, 10, 231. [CrossRef]

48. Shi, A.; Shirowzhan, S.; Sepasgozar, S.M.; Kaboli, A. 5D BIM Applications in Quantity Surveying: Dynamo and 3D Printing Technologies. In Smart Cities and Construction Technologies; IntechOpen: London, UK, 2020. [CrossRef]

49. Tahmasebinia, F.; Sepasgozar, S.M.; Shirowzhan, S.; Niemela, M.; Tripp, A.; Nagabhyrava, S.; Alonso-Marroquin, F. Criteria development for sustainable construction manufacturing in Construction Industry 4.0. Constr. Innov. 2020, 20, 379-400. [CrossRef]

50. Tankova, T.; da Silva, L.S. Robotics and Additive Manufacturing in the Construction Industry. Curr. Robot. Rep. 2020, 1, 13-18. [CrossRef]

51. Shirowzhan, S.; Lim, S.; Trinder, J.; Li, H.; Sepasgozar, S.M.E. Data mining for recognition of spatial distribution patterns of building heights using airborne lidar data. Adv. Eng. Inform. 2020, 43, 101033. [CrossRef]

52. Shirowzhan, S.; Sepasgozar, S.M.E.; Li, H.; Trinder, J. Spatial compactness metrics and Constrained Voxel Automata development for analyzing 3D densification and applying to point clouds: A synthetic review. Autom. Constr. 2018, 96, 236-249. [CrossRef]

53. Sepasgozar, S.M.; Lim, S.; Shirowzhan, S. Implementation of Rapid As-built Building Information Modeling Using Mobile LiDAR. In Proceedings of the Construction Research Congress 2014, Construction in a Global Network, Atlanta, Georgia, 19-21 May 2014; pp. 209-218.

54. Sepasgozar, S.M.; Wang, C.; Shirowzhan, S. Challenges and Opportunities for Implementation of Laser Scanners in Building Construction. In Proceedings of the 33rd International Symposium on Automation and Robotics in Construction (ISARC 2016), Auburn, AL, USA, 18 July 2016; pp. 742-751.

55. Gheisari, M.; Esmaeili, B. Unmanned aerial systems (UAS) for construction safety applications. In Proceedings of the Construction Research Congress 2016, San Juan, Puerto Rico, 31 May-2 June 2016; pp. 2642-2650.

56. Gheisari, M.; Esmaeili, B. Applications and requirements of unmanned aerial systems (UASs) for construction safety. Saf. Sci. 2019, 118, 230-240. [CrossRef]

57. Moselhi, O.; Bardareh, H.; Zhu, Z. Automated data acquisition in construction with remote sensing technologies. Appl. Sci. 2020, 10, 2846. [CrossRef]

58. Li, H.; Chan, G.; Wong, J.K.W.; Skitmore, M. Real-time locating systems applications in construction. Autom. Constr. 2016, 63, 37-47. [CrossRef]

59. Boschert, S.; Heinrich, C.; Rosen, R. Next generation digital twin. In Proceedings of the Tmce (Tools and Methods of Competitive Engineering), Las Palmas de Gran Canaria, Spain, 7-11 May 2018; pp. 209-218.

60. Sepasgozar, S.M. Digital Twin and Web-Based Virtual Gaming Technologies for Online Education: A Case of Construction Management and Engineering. Appl. Sci. 2020, 10, 4678. [CrossRef]

61. Sepasgozar, S.M.E.; Hui, F.K.P.; Shirowzhan, S.; Foroozanfar, M.; Yang, L.; Aye, L. Lean Practices Using Building Information Modeling (BIM) and Digital Twinning for Sustainable Construction. Sustainability 2021, 13, 161. [CrossRef]

62. Ruiz-Rosero, J.; Ramirez-Gonzalez, G.; Williams, J.M.; Liu, H.; Khanna, R.; Pisharody, G. Internet of things: A scientometric review. Symmetry 2017, 9, 301. [CrossRef]

63. Sepasgozar, S.M.; Karimi, R.; Shirowzhan, S.; Mojtahedi, M.; Ebrahimzadeh, S.; McCarthy, D. Delay Causes and Emerging Digital Tools: A Novel Model of Delay Analysis, Including Integrated Project Delivery and PMBOK. Buildings 2019, 9, 191. [CrossRef]

64. Sood, S.K.; Rawat, K.S. A scientometric analysis of ICT-assisted disaster management. Nat. Hazards 2021, 1-19.

65. Khan, A.; Sepasgozar, S.; Liu, T.; Yu, R. Integration of BIM and Immersive Technologies for AEC: A Scientometric-SWOT Analysis and Critical Content Review. Buildings 2021, 11, 126. [CrossRef]

66. Errandonea, I.; Beltrán, S.; Arrizabalaga, S. Digital Twin for maintenance: A literature review. Comput. Ind. 2020, $123,103316$. [CrossRef]

67. Kaewunruen, S.; Rungskunroch, P.; Welsh, J. A digital-twin evaluation of net zero energy building for existing buildings. Sustainability 2019, 11, 159. [CrossRef]

68. Shafto, M.; Conroy, M.; Doyle, R.; Glaessgen, E.; Kemp, C.; LeMoigne, J.; Wang, L. Modeling, simulation, information technology \& processing roadmap. Natl. Aeronaut. Space Adm. 2012, TA 11,1-170.

69. Brenner, B.; Hummel, V. Digital twin as enabler for an innovative digital shopfloor management system in the ESB Logistics Learning Factory at Reutlingen-University. Procedia Manuf. 2017, 9, 198-205. [CrossRef]

70. Padovano, A.; Longo, F.; Nicoletti, L.; Mirabelli, G. A digital twin based service oriented application for a 4.0 knowledge navigation in the smart factory. IFAC-PapersOnLine 2018, 51, 631-636. [CrossRef] 
71. Zhang, H.; Yan, Q.; Wen, Z. Information modeling for cyber-physical production system based on digital twin and AutomationML. Int. J. Adv. Manuf. Technol. 2020, 1-19. [CrossRef]

72. Wang, P.; Luo, M. A digital twin-based big data virtual and real fusion learning reference framework supported by industrial internet towards smart manufacturing. J. Manuf. Syst. 2021, 58, 16-32. [CrossRef]

73. Chen, G.; Wang, P.; Feng, B.; Li, Y.; Liu, D. The framework design of smart factory in discrete manufacturing industry based on cyber-physical system. Int. J. Comput. Integr. Manuf. 2020, 33, 79-101. [CrossRef]

74. Luo, W.; Hu, T.; Zhang, C.; Wei, Y. Digital twin for CNC machine tool: Modeling and using strategy. J. Ambient Intell. Humaniz. Comput. 2019, 10, 1129-1140. [CrossRef]

75. Hochhalter, J.D.; Leser, W.P.; Newman, J.A.; Glaessgen, E.H.; Gupta, V.K.; Yamakov, V.; Cornell, S.R.; Willard, S.A.; Heber, G Coupling Damage-Sensing Particles to the Digitial Twin Concept; National Aeronautics and Space Administration, Langley Research Center: Hampton, VA, USA, 2014.

76. Söderberg, R.; Wärmefjord, K.; Carlson, J.S.; Lindkvist, L. Toward a Digital Twin for real-time geometry assurance in individualized production. CIRP Ann. 2017, 66, 137-140. [CrossRef]

77. Schluse, M.; Priggemeyer, M.; Atorf, L.; Rossmann, J. Experimentable digital twins-Streamlining simulation-based systems engineering for industry 4.0. IEEE Trans. Ind. Inform. 2018, 14, 1722-1731. [CrossRef]

78. He, Y.; Guo, J.; Zheng, X. From surveillance to digital twin: Challenges and recent advances of signal processing for industrial internet of things. IEEE Signal Process. Mag. 2018, 35, 120-129. [CrossRef]

79. Cimino, C.; Negri, E.; Fumagalli, L. Review of digital twin applications in manufacturing. Comput. Ind. 2019, 113, 103130. [CrossRef]

80. Bao, J.; Guo, D.; Li, J.; Zhang, J. The modelling and operations for the digital twin in the context of manufacturing. Enterp. Inf. Syst. 2019, 13, 534-556. [CrossRef]

81. Kaewunruen, S.; Lian, Q. Digital twin aided sustainability-based lifecycle management for railway turnout systems. J. Clean. Prod. 2019, 228, 1537-1551. [CrossRef]

82. Grieves, M.; Vickers, J. Digital twin: Mitigating unpredictable, undesirable emergent behavior in complex systems. In Transdisciplinary Perspectives on Complex Systems; Springer: Berlin, Germany, 2017; pp. 85-113.

83. Luo, C.; Franciosa, P.; Mo, Z.; Ceglarek, D. A Framework for Tolerance Modeling Based on Parametric Space Envelope. J. Manuf. Sci. Eng. 2020, 142, 061007. [CrossRef]

84. Kwon, S.; Monnier, L.V.; Barbau, R.; Bernstein, W.Z. Enriching standards-based digital thread by fusing as-designed and as-inspected data using knowledge graphs. Adv. Eng. Inform. 2020, 46, 101102. [CrossRef]

85. Lee, J.; Azamfar, M.; Singh, J.; Siahpour, S. Integration of digital twin and deep learning in cyber-physical systems: Towards smart manufacturing. IET Collab. Intell. Manuf. 2020, 2, 34-36. [CrossRef]

86. Magargle, R.; Johnson, L.; Mandloi, P.; Davoudabadi, P.; Kesarkar, O.; Krishnaswamy, S.; Batteh, J.; Pitchaikani, A. A simulationbased digital twin for model-driven health monitoring and predictive maintenance of an automotive braking system. In Proceedings of the 12th International Modelica Conference, Prague, Czech Republic, 15-17 May 2017; pp. $35-46$.

87. El Saddik, A. Digital twins: The convergence of multimedia technologies. IEEE Multimed. 2018, 25, 87-92. [CrossRef]

88. Jiang, Z.; Guo, Y.; Wang, Z. Digital twin to improve the virtual-real integration of industrial IoT. J. Ind. Inf. Integr. 2021, 22, 100196. [CrossRef]

89. Tabar, R.S.; Wärmefjord, K.; Söderberg, R. A method for identification and sequence optimisation of geometry spot welds in a digital twin context. Proc. Inst. Mech. Eng. Part C J. Mech. Eng. Sci. 2019, 233, 5610-5621. [CrossRef]

90. Schleich, B.; Anwer, N.; Mathieu, L.; Wartzack, S. Shaping the digital twin for design and production engineering. CIRP Ann, 2017, 66, 141-144. [CrossRef]

91. Tao, F.; Zhang, H.; Liu, A.; Nee, A.Y. Digital twin in industry: State-of-the-art. IEEE Trans. Ind. Inform. 2018, 15, 2405-2415. [CrossRef]

92. Uhlemann, T.H.J.; Lehmann, C.; Steinhilper, R. The Digital Twin: Realizing the Cyber-Physical Production System for Industry 4.0. Procedia CIRP 2017, 61, 335-340. [CrossRef]

93. Fan, C.; Zhang, C.; Yahja, A.; Mostafavi, A. Disaster City Digital Twin: A vision for integrating artificial and human intelligence for disaster management. Int. J. Inf. Manag. 2019, 56, 102049. [CrossRef]

94. Leng, J.; Zhang, H.; Yan, D.; Liu, Q.; Chen, X.; Zhang, D. Digital twin-driven manufacturing cyber-physical system for parallel controlling of smart workshop. J. Ambient Intell. Humanized Comput. 2019, 10, 1155-1166. [CrossRef]

95. Bauer, P.; Stevens, B.; Hazeleger, W. A digital twin of Earth for the green transition. Nat. Clim. Chang. 2021, 11, 1-4. [CrossRef]

96. Ford, D.N.; Wolf, C.M. Smart cities with digital twin systems for disaster management. J. Manag. Eng. 2020, $36,04020027$. [CrossRef]

97. White, G.; Zink, A.; Codecá, L.; Clarke, S. A digital twin smart city for citizen feedback. Cities 2021, 110, 103064. [CrossRef]

98. Zaballos, A.; Briones, A.; Massa, A.; Centelles, P.; Caballero, V. A Smart Campus' Digital Twin for Sustainable Comfort Monitoring. Sustainability 2020, 12, 9196. [CrossRef]

99. Francisco, A.; Mohammadi, N.; Taylor, J.E. Smart City Digital Twin-Enabled Energy Management: Toward Real-Time Urban Building Energy Benchmarking. J. Manag. Eng. 2020, 36, 04019045. [CrossRef]

100. McNamara, A.J.; Sepasgozar, S.M. Developing a theoretical framework for intelligent contract acceptance. Constr. Innov. 2020, 20, 421-445. [CrossRef] 
101. Zhang, M.; Zuo, Y.; Tao, F. Equipment energy consumption management in digital twin shop-floor: A framework and potential applications. In Proceedings of the 2018 IEEE 15th International Conference on Networking, Sensing and Control (ICNSC), Zhuhai, China, 27-29 March 2018; pp. 1-5.

102. He, B.; Bai, K.-J. Digital twin-based sustainable intelligent manufacturing: A review. Adv. Manuf. 2020. [CrossRef]

103. Raj, P. Empowering digital twins with blockchain. Adv. Comput. 2021, 121, 267.

104. Gopinath, V.; Srija, A.; Sravanthi, C.N. Re-design of smart homes with digital twins. J. Phys. Conf. Ser. 2019, 1228, 012031. Available online: https:/ / www.researchgate.net/publication/333573394_Re-design_of_smart_homes_with_digital_twins (accessed on 24 February 2021).

105. Sepasgozar, S.; Lim, S.; Shirowzhan, S.; Kim, Y.; Nadoushani, Z.M. Utilisation of a New Terrestrial Scanner for Reconstruction of As-built Models: A Comparative Study. In Proceedings of the 32nd International Symposium on Automation and Robotics in Construction and Mining, Oulu, Finland, 15-18 June 2015; p. 1.

106. Sepasgozar, S.M.; Forsythe, P.; Shirowzhan, S. Evaluation of terrestrial and mobile scanner technologies for part-built information modeling. J. Constr. Eng. Manag. 2018, 144, 04018110. [CrossRef]

107. Sepasgozar, S.M.E.; Lim, S.; Shirowzhan, S.; Kim, Y.M. Implementation of As-Built Information Modelling Using Mobile and Terrestrial Lidar Systems. In Proceedings of the The 31st International Symposium on Automation and Robotics in Construction and Mining (ISARC 2014), Sydney, Australia, 9-11 July 2014.

108. Tahmasebinia, F.; Niemelä, M.; Ebrahimzadeh Sepasgozar, S.; Lai, T.; Su, W.; Reddy, K.; Shirowzhan, S.; Sepasgozar, S.; Marroquin, F. Three-Dimensional Printing Using Recycled High-Density Polyethylene: Technological Challenges and Future Directions for Construction. Buildings 2018, 8, 165. [CrossRef]

109. Bauernhansl, T. WGP-Standpunkt Industrie 4.0; Wissenschaftliche Gesellschaft für Produktionstechnik: Germany, 2016; Available online: https://www.ipa.fraunhofer.de/content/dam/ipa/de/documents/Presse/Presseinformationen/2016/Juni/ WGP_Standpunkt_Industrie_40.pdf (accessed on 24 February 2021). 